\title{
Soil CEC Predicting Model of Tobacco-Planting Fields in Chenzhou, South Hunan Province
}

\author{
Y S XIAO ${ }^{a}, \mathrm{Z} \mathrm{H} \mathrm{CAO}^{\text {a }}, \mathrm{W} \mathrm{J} \mathrm{LI}^{\mathrm{a}}$, Y H LIAO ${ }^{\mathrm{b}}$, \\ $\mathrm{B} \mathrm{HE}^{\mathrm{a}}, \mathrm{L} \mathrm{J} \mathrm{LI}^{\mathrm{a}}, \mathrm{Z} \mathrm{H} \mathrm{HE}^{\mathrm{a}}$, Q ZHONG ${ }^{\mathrm{c}, ~} 1$ \\ ${ }^{a}$ Chenzhou Tobacco Company of Hunan Province, Chenzhou, Hunan 423000, China \\ ${ }^{b}$ Hunan Provincial Tobacco Company, Changsha 410010, China \\ ${ }^{c}$ Yongxing Branch of Chenzhou Tobacco Company, Yongxing Hunan 423300, China
}

\begin{abstract}
Background] Cation exchange capacity (CEC) is a basic but important soil property of soil fertility or quality, CEC predicting model is often derived from other soil properties measured more easily because the traditional method determining CEC is time-consuming and laborious. It is necessary to establish a new CEC prediction model for a new region because CEC predicting model usually is dependent on the study region. [Objective] Chenzhou City is the most important and typical tobacco-planting region with tobacco-rice rotation in Hunan province and China, this study was conducted to establish CEC predicting model for the tobacco-planting fields in Chenzhou because so far no CEC predicting model is available for tobacco-planting fields in Chenzhou and in China. [Method] In total 1055 topsoil samples $(0 \sim 20 \mathrm{~cm})$ were collected in 2015 from the tobacco-planting fields in Chenzhou, soil properties included the particle size composition, $\mathrm{pH}$, soil organic matter and various nutrients were determined, the status of CEC were assessed, and then CEC predicting models were setup in different regions in Chenzhou. [Result] The results showed that CEC in Chenzhou was ranged from 3.50 to $48.50 \mathrm{cmol}(+) \mathrm{kg}^{-1}$ with a mean of $22.05 \mathrm{cmol}(+) \mathrm{kg}^{-1}$, averagely belonged to the very high grade $\left(>20 \mathrm{cmol}(+) \mathrm{kg}^{-1}\right)$. There were significant differences in CECs in different regions in Chenzhou, which was the highest in Jiahe $\left(23.83 \mathrm{cmol}(+) \mathrm{kg}^{-1}\right)$ but the lowest in Anren $\left(15.78 \mathrm{cmol}(+) \mathrm{kg}^{-1}\right)$. CEC was significantly correlated with different soil properties in different regions, which was significantly correlated with coarse sands, fine sands, clays, $\mathrm{pH}$ and total $\mathrm{P}$ in Chenzhou $\left(\mathrm{R}=0.312^{* *} \sim 0.445^{* *}\right)$, significantly correlated with coarse sands, silts, fine sands, clays, $\mathrm{pH}$, total $\mathrm{P}$, exchangeable $\mathrm{Ca}^{2+}, \mathrm{Mg}^{2+}$ and available $\mathrm{Zn}$ in Suxian $\left(\mathrm{R}=0.430^{* *} \sim 0.684^{* *}\right)$, significantly correlated with coarse sands, fine sands, silts, clays, $\mathrm{pH}$, total $\mathrm{P}$, available $\mathrm{B}$ and $\mathrm{Cu}$ in Yongxing $\left(\mathrm{R}=0.321^{* *} \sim 0.605^{* *}\right)$, significantly correlated with coarse sands, fine sands and clays and total $\mathrm{P}$ in Guiyang $\left(\mathrm{R}=0.330^{* *} \sim 0.477^{* *}\right)$, significantly correlated with coarse sands, silts and total $\mathrm{K}$ in Yizhang $\left(\mathrm{R}=0.326^{* *} \sim 0.466^{* *}\right)$, and only significantly correlated with fine sands in Jiahe $\left(\mathrm{R}=0.350^{* *}\right)$. The accuracy of CEC predicting model usually was lower when less properties involved. Based on the comparison of the $\mathrm{R}^{2}$ and RMSE of the established CEC predicting models, it is recommended that the total model for Chenzhou could be used for Guiyang, Jiahe and Yizhang, while the regional models should be selected for Yongxing, Anren and Suxian. [Conclusion] This study proves further that different soil properties were most important for CEC predicting models in different regions, new CEC predicting models must be setup for a new study region, and soil organic matter is
\end{abstract}

1 Corresponding author: Yongxing Branch of Chenzhou Tobacco Company, Yongxing Hunan 423300, China; E-mail: zhqu126@126.com. 
not a variable in soil CEC predicting models for tobacco-planting fields in Chenzhou, which are different from some previous studies.

Keywords. soil CEC, statistic information, correlation, predicting model

\section{Introduction}

Cation exchange capacity (CEC) is a basic soil property often used as an index of soil fertility or quality, understanding CEC plays important roles in guiding reasonable fertilization and soil improvement [1-2]. Meanwhile, CEC is also an index for soil classification or taxonomy [3-4]. Because the traditional methods determining CEC are time-consuming and laborious, more studies were conducted to setup CEC predicting model from soil properties measured more easily [5-14], and the results showed that for different regions or soils, the variables used in predicting soil CEC are different, for examples, Rahal and Alhumairi [5] predicted soil CEC in mid-Mesopotamian plain by using texture class, bulk density, total available water content, soil color, sodium adsorption ratio, electrical conductivity and $\mathrm{Ca} 2+$. Khaledian et al. [6] proved that soil CEC was affected by different variables in different situations, clay (positively correlated) and sand (negatively correlated) were the most influential variables for predicting CEC, CEC was significantly and negatively correlated with $\mathrm{pH}$ in agricultural land uses in Spain, significant positive relationship between CEC and OC in Spain, the USA, Iraq, and pasture. Shiri et al. [7] used the contents of silts, clays, sands, organic carbon and $\mathrm{pH}$ in modeling soil CEC in Iran. Seyedmohammadi et al. [8] proved soil organic carbon and claycould be used as input variables (positively correlated) for predicting CEC of paddy soils in Guilan province, northern Iran. Liao et al. [9] modeled soil CEC with organic matter, silt, clay and $\mathrm{pH}$ (positively correlated) as well as sand (negatively correlated) in Qingdao in China. Obalum et al. [10] found that CEC of coarse-textured soils in southeastern Nigeria increased with decreasing coarse sand but with increasing fine sand, silt correlated negatively with the CEC, clay and organic matter generally impacted positively on the CEC, and the best-fitting linear CEC function was attained with fine sand, clay, and organic matter. Yukselen and Kaya [11] predicted soil CEC in Hawaii by using organic matter and clay fraction (positively correlated) with other variables (specific surface area, activity, Atterberg limits, plastic, shrinkage, and modified free swell index). Seybold et al. [12] used organic matter and clay content (positively correlated) and $\mathrm{pH}$ (positively or negatively correlated) as the main variables to model soil CEC in USA. Krogh et al. [13] found that CEC of Danish soils could be modelled with clay and organic matter content (positively correlated), while silt and $\mathrm{pH}$ (positively correlated) might also contribute as predictor variables. Manrique et al. [14] found that clay, organic carbon (positively correlated) and $\mathrm{pH}$ (negatively correlated) could be used in predicting CECs for all soils, while clay and organic carbon used in predicting CECs of Alfisols, Inceptisols, Mollisols, Vertisols, Entisols, Spodosols, Spodosols.

For tobacco-planting soils in China, CEC is often measured and used as an index of soil fertility [15-23], and the relationship between CEC and other properties were also discussed in some studies [24-27]. Furthermore, some studies found that CEC is closely related to the chemical components of tobacco leaves (total sugar, reducing sugar, salt and nicotine etc.) [28-29], and high CEC is conducive to reducing the occurrence and harm of bacterial wilt and red weed diseases of tobacco [30-31]. 
Chenzhou City of south Hunan Province, with a long history of tobacco-planting as early as in 1593 and where most paddy fields are under tobacco-rice rotation [32], is the most important and typical planting region of flue-cured tobacco with burnt-pure sweet aroma in China [33]. The area of tobacco-planting in Chenzhou is about $26.7 \times 10^{3} \mathrm{hm}^{2}$ in recent years, which plays an important role in ensuring the supply of high-quality tobacco leaves and the sustainable development of regional society and economy. Some literatures were published about tobacco-planting soil characteristics in Chenzhou [34-37]. Nowadays, a new round of tobacco-planting soil improvement is underway in Chenzhou and in other regions of China, it is helpful to understand further soil CEC in tobacco-planting fields in providing scientific instruction for this work, However, so far little information is available on soil CEC predicting model for tobacco-planting fields in Chenzhou and China, thus, in this study, the status of soil CEC in tobacco-planting fields in Chenzhou were studied and CEC predicting models were setup based on other soil properties.

\section{Methods and Materials}

\subsection{Sources of Soil Data}

The data of soil properties used in this study came from the tobacco-planting soil surveys conducted in 2015, which included 1055 topsoil samples $(0 \sim 20 \mathrm{~cm})$ collected from the typical tobacco-planting fields in different regions of Chenzhou.

The typical field was decided according to the spatial distribution uniformity of the tobacco-planting field, in each typical field the topsoil sample was collected randomly at 5 8 points with stainless steel drill and then were mixed completely. The measured soil properties were included particle composition, $\mathrm{pH}\left(\mathrm{H}_{2} \mathrm{O}\right)$, organic matter $(\mathrm{OM})$, total nitrogen (TN), phosphorous (TP) and potassium (TK), available nitrogen (AN), phosphorous (AP) and potassium (AK), exchangeable calcium $\left(\mathrm{Ca}^{2+}\right)$ and magnesium $\left(\mathrm{Mg}^{2+}\right)$, available sulfur (S), water-soluble chlorine $\left(\mathrm{Cl}^{-}\right)$, and available boron (B), iron $(\mathrm{Fe})$, manganese $(\mathrm{Mn})$, copper $(\mathrm{Cu})$, zinc $(\mathrm{Zn})$ and molybdenum $(\mathrm{Mo})$. The detailed determination methods for soil properties could be found in related literatures [38-41].

\subsection{Grading Standard of Soil CEC}

No information was available in China on the grading standard of soil CEC for tobacco-planting fields, in this study, soil CEC in Chenzhou was divided into 5 grades as shown in Table 1 which was based on soil CEC classification of the $2^{\text {nd }}$ national soil survey [42-43].

Table 1. Grading standard of soil CEC for tobacco-planting field in Chenzhou.

\begin{tabular}{cccccc}
\hline Grade & Very low & Low & Middle & High & Very high \\
\hline Value $\operatorname{cmol}(+) \mathrm{kg}^{-1}$ & $<6.2$ & $6.2 \sim 10.5$ & $10.5 \sim 15.4$ & $15.4 \sim 20$ & $\geq 20$ \\
\hline
\end{tabular}




\subsection{Data Processing and Statistics}

Microsoft Excel 2016 and IBM Statistics SPSS 22.0 software were used for statistical analysis of the data, and Duncan test method (2-tailed) was used for variance analyses and multiple comparisons [43-44].

\section{Results}

\subsection{Statistics and Comparison of CEC}

Table 2 shows the statistical results of CEC. CEC was ranged from 3.50 to 48.50 $\operatorname{cmol}(+) \mathrm{kg}^{-1}$ with a mean of $22.05 \mathrm{cmol}(+) \mathrm{kg}^{-1}$, which covered the whole 5 grades, but averagely belonged to the very high grade $\left(>20 \mathrm{cmol}(+) \mathrm{kg}^{-1}\right)$. Meanwhile, for total samples, CEC was in the moderate middle variation (C.V. $=61.08 \%<100 \%$ ), very positive skewness distribution (Skewness $>0.3$ ) and flat peak distribution (Kurtosis $\approx 0$ ) [44-45].

CEC was the highest in Yongxing $\left(24.11 \mathrm{cmol}(+) \mathrm{kg}^{-1}\right)$ but the lowest in Anren $\left(15.31 \mathrm{cmol}^{+}+\mathrm{kg}^{-1}\right)$. CEC of Yongxing was not significantly higher than those of Jiahe and Guiyang, but significantly higher than those of other regions. CEC of Jiahe was not significantly higher than those of Guiyang and Beihu, but significantly higher than those of Yizhang, Suxian, Linwu and Anren. CEC of Guiyang was not significantly higher than that of Beihu, but significantly higher than thoese of Yizhang, Suxian, Linwu and Anren, CEC of Beihu was not significantly higher than that of Yizhang, but significantly higher than those of Suxian, Linwu and Anren, CEC of Yizhang was significantly higher than those of Suxian, Linwu and Anren, while no significant difference was found among Suxian, Linwu and Anren.

Table 2. Statistic information of tobacco-planting soil CECs in Chenzhou.

\begin{tabular}{lllllllll}
\hline Region & $\begin{array}{l}\text { Sample } \\
\text { no. }\end{array}$ & $\begin{array}{l}\text { Minimum } \\
\mathrm{cmol} \\
\mathrm{kg}^{-1}\end{array}$ & $\begin{array}{l}\text { Maximum } \\
\mathrm{Cmol} \\
\mathrm{kg}^{-1}\end{array}$ & $\begin{array}{l}\text { Mean } \pm \text { S.D. } \\
\mathrm{Cmol}(+) \mathrm{kg}^{-1}\end{array}$ & C.V. $(\%)$ & Skewness & Kurtosis \\
\hline Total & 1055 & 3.5 & 48.5 & $22.05 \pm 7.70$ & 34.9 & 0.45 & 0.01 \\
Guiyang & 560 & 3.5 & 48.5 & $23.80 \pm 7.62 \mathrm{ace}$ & 32.02 & 0.42 & 0.01 \\
Yongxing & 115 & 6.3 & 45 & $24.11 \pm 8.17 \mathrm{a}$ & 33.88 & -0.01 & -0.15 \\
Jiahe & 110 & 9.3 & 40.4 & $23.83 \pm 6.32 \mathrm{ac}$ & 26.51 & 0.41 & 0 \\
Anren & 100 & 5.8 & 30.7 & $15.31 \pm 5.15 \mathrm{k}$ & 33.62 & 0.4 & -0.17 \\
Yizhang & 96 & 6.2 & 37.6 & $18.10 \pm 5.77 \mathrm{dfgi}$ & 31.86 & 0.8 & 0.53 \\
Suxian & 45 & 6.2 & 27.6 & $16.30 \pm 4.92 \mathrm{hjk}$ & 30.2 & -0.05 & -0.16 \\
Beihu & 17 & 14.7 & 29.1 & $20.88 \pm 3.94 \mathrm{bceg}$ & 18.88 & 0.44 & 0.18 \\
Linwu & 12 & 8.8 & 28.6 & $15.78 \pm 5.70 \mathrm{k}$ & 36.16 & 1.22 & 1.24 \\
\hline
\end{tabular}

Note: values in the same column followed by different lowercase letters are significantly different at the 0.05 level.

\subsection{Statistics and Comparison of Soil CEC in Each Grade}

Table 3 shows the statistical results of the numbers and proportions of tobacco-planting fields in different grades of CEC. For all the samples in Chenzhou and the samples in Guiyang, Yongxing, Jiahe and Beihu, the sample proportions were all in the order of 
the very high grade $>$ the high grade $>$ the middle grade $>$ the low grade $>$ very low grade, and the sample proportion of the very high grade was $57.25 \% \sim 74.78 \%$. However, for the samples in Anren, the sample proportion was in the order of the middle grade $(32.00 \%)>$ the high grade $(29.00 \%)>$ the low grade $(20.00 \%)>$ the very high grade $(18.00 \%)>$ the very low grade $(1.00 \%)$, while for the samples in Yizhang and Suxian, the sample proportions were both in the order of the high grade $(34.38 \%$ and $35.56 \%)>$ the middle grade $(32.29 \%$ and $28.89 \%)>$ the very high grade $(29.17 \%$ and $24.44 \%)>$ the low grade $(4.17 \%$ and $11.11 \%)$, and no sample in the very low grade.

Table 3. Sample numbers and proportions in different grades of CEC.

\begin{tabular}{|c|c|c|c|c|c|c|c|c|c|c|}
\hline \multirow{2}{*}{ Region } & \multicolumn{2}{|c|}{ Very high $(\geq 20)$} & \multicolumn{2}{|c|}{ High (15.4 20) } & \multicolumn{2}{|c|}{$\begin{array}{c}\text { Middle } \\
(10.5 \sim 15.4)\end{array}$} & \multicolumn{2}{|c|}{ Low $(6.2 \sim 10.5)$} & \multicolumn{2}{|c|}{$\begin{array}{c}\text { Very low } \\
(<6.2)\end{array}$} \\
\hline & $\begin{array}{c}\text { Sample } \\
\text { no. }\end{array}$ & $\%$ & $\begin{array}{c}\text { Sample } \\
\text { no. }\end{array}$ & $\%$ & $\begin{array}{c}\text { Sample } \\
\text { no. }\end{array}$ & $\%$ & $\begin{array}{c}\text { Sample } \\
\text { no. }\end{array}$ & $\%$ & $\begin{array}{c}\text { Sample } \\
\text { no. }\end{array}$ & $\%$ \\
\hline Total & 604 & 57.25 & 239 & 22.66 & 160 & 15.17 & 47 & 4.45 & 5 & 0.47 \\
\hline Guiyang & 367 & 65.54 & 122 & 21.79 & 60 & 10.71 & 7 & 1.25 & 4 & 0.71 \\
\hline Yongxing & 86 & 74.78 & 10 & 8.70 & 10 & 8.70 & 9 & 7.83 & 0 & 0 \\
\hline Jiahe & 81 & 73.64 & 21 & 19.09 & 7 & 6.36 & 1 & 0.91 & 0 & 0 \\
\hline Anren & 18 & 18.00 & 29 & 29.00 & 32 & 32.00 & 20 & 20.00 & 1 & 1.00 \\
\hline Yizhang & 28 & 29.17 & 33 & 34.38 & 31 & 32.29 & 4 & 4.17 & 0 & 0 \\
\hline Suxian & 11 & 24.44 & 16 & 35.56 & 13 & 28.89 & 5 & 11.11 & 0 & 0 \\
\hline Beihu & 11 & 64.71 & 4 & 23.53 & 2 & 11.76 & 0 & 0 & 0 & 0 \\
\hline Linwu & 2 & 16.67 & 4 & 33.33 & 5 & 41.67 & 1 & 8.33 & 0 & 0 \\
\hline
\end{tabular}

\subsection{Correlation between CEC and Other Properties}

Table 4 shows the statistical results of other soil properties while Table 5 shows the Pearson correlation coefficients between CEC and other properties. It can be seen from Table 5 that CEC was significantly correlated with different properties in different regions, for examples, CEC was significantly correlated with coarse sands, fine sands, clays and TP for all samples in Chenzhou $\left(\mathrm{R}=0.312^{* *} \sim 0.445^{* *}\right.$, in this paper only soil properties with $\mathrm{R} \geq 0.3^{* *}$ was used to setup CEC predicting model, because this value usually means significant correlation existed [44-45]), significantly correlated with coarse sands, fine sands, silts, clays, $\mathrm{pH}, \mathrm{TP}, \mathrm{Ca}^{2+}, \mathrm{Mg}^{2+}$ and $\mathrm{Zn}$ for samples in Suxian $\left(\mathrm{R}=0.430^{* *} \sim 0.684^{* *}\right)$, significantly correlated with coarse sands, fine sands, silts, clays and $\mathrm{pH}, \mathrm{TP}, \mathrm{B}$ and $\mathrm{Cu}$ for samples in Yongxing $\left(\mathrm{R}=0.321^{* *} \sim 0.605^{* *}\right)$, significantly correlated with coarse sands, fine sands and clays and TP for samples in Guiyang $\left(\mathrm{R}=-0.330^{* *} \sim 0.477^{* *}\right)$, and only significantly correlated with fine sands for samples in Jiahe $\left(\mathrm{R}=0.350^{* *}\right)$.

According to the significant correlation existed between $\mathrm{CEC}$ and other properties, the optimal regression models of CEC were established for Chenzhou and for different regions in Chenzhou (see Table 6). If judged from $\mathrm{R}^{2}$ and RMSE/S.D., the accuracy was higher for soil CEC predicting models in Suxian, Anren and Yongxing $\left(\mathrm{R}^{2}=0.795^{* *}\right.$, $0.602^{* *}$ and $0.489^{* *}$, and $\mathrm{RMSE} / \mathrm{S} . \mathrm{D}=0.57,0.66$ and 0.74 , respectively), but the accuracy was lower for soil CEC predicting models in Jiahe, Guiyang and Yizhang $\left(\mathrm{R}^{2}=0.123,0.288\right.$ and 0.231 and $\mathrm{RMSE} / \mathrm{S} . \mathrm{D}=0.94,0.85$ and 0.89 , respectively $)$. Thus, it is recommended that for Yongxing, Anren and Suxian, their own regional models 
should be used to predict soil CEC, but for Guiyang, Jiahe and Yizhang, the total model could be considered to predict soil CEC.

Table 4. Statistic information of other soil properties in Chenzhou $(n=1055)$.

\begin{tabular}{|c|c|c|c|c|c|c|}
\hline Soil property & Minimum & Maximum & Mean \pm S.D. & C.V. & Skewness & Kurtosis \\
\hline Coarse sands & 0 & 56 & $8 \pm 5$ & 61.08 & 2.89 & 15.51 \\
\hline Fine sands & 4 & 64 & $25 \pm 8$ & 31.87 & 1.10 & 2.18 \\
\hline Silts & 10 & 56 & $38 \pm 7$ & 17.76 & -0.64 & 0.73 \\
\hline Clays & 10 & 66 & $29 \pm 8$ & 27.54 & 0.37 & 0.10 \\
\hline $\mathrm{pH}$ & 4.47 & 8.14 & $7.00 \pm 0.93$ & 13.35 & -0.97 & -0.34 \\
\hline OM & 0.90 & 132.30 & $48.00 \pm 14.38$ & 29.95 & 0.56 & 1.14 \\
\hline TN & 1.06 & 5.26 & $2.66 \pm 0.71$ & 26.76 & 0.41 & 0.10 \\
\hline $\mathrm{AN}$ & 64.70 & 447.40 & $202.98 \pm 54.07$ & 26.64 & 0.46 & 0.51 \\
\hline $\mathrm{TP}$ & 0.27 & 2.84 & $0.92 \pm 0.28$ & 30.28 & 0.32 & 1.78 \\
\hline AP & 1.66 & 118.80 & $36.48 \pm 17.74$ & 48.62 & 0.89 & 1.40 \\
\hline TK & 18.60 & 725.70 & $205.71 \pm 87.51$ & 42.54 & 0.68 & 1.25 \\
\hline $\mathrm{AK}$ & 6.22 & 40.10 & $12.74 \pm 3.83$ & 30.05 & 2.33 & 10.16 \\
\hline $\mathrm{Ca}^{2+}$ & 2.11 & 83.77 & $33.27 \pm 23.35$ & 70.19 & 0.62 & -1.00 \\
\hline $\mathrm{Mg}^{2+}$ & 0.08 & 7.55 & $1.65 \pm 1.04$ & 63.21 & 1.25 & 2.02 \\
\hline $\mathrm{S}$ & 7.40 & 594.57 & $39.42 \pm 35.83$ & 90.89 & 8.26 & 107.76 \\
\hline $\mathrm{Cl}^{-}$ & 0.00 & 98.09 & $6.30 \pm 9.84$ & 156.19 & 2.72 & 11.96 \\
\hline B & 0.19 & 1.36 & $0.55 \pm 0.18$ & 32.59 & 1.05 & 1.88 \\
\hline $\mathrm{Fe}$ & 10.80 & 502.10 & $142.86 \pm 89.59$ & 62.71 & 1.23 & 1.23 \\
\hline $\mathrm{Mn}$ & 0.81 & 294.20 & $33.24 \pm 31.53$ & 94.87 & 2.94 & 12.37 \\
\hline $\mathrm{Cu}$ & 0.27 & 96.30 & $4.70 \pm 5.31$ & 113.05 & 12.66 & 190.18 \\
\hline $\mathrm{Zn}$ & 0.42 & 233.00 & $4.44 \pm 9.77$ & 220.12 & 15.65 & 318.23 \\
\hline Mo & 0.00 & 4.40 & $0.16 \pm 0.23$ & 143.79 & 8.18 & 124.05 \\
\hline
\end{tabular}

Note: Coarse sands, Fine sands, Silts and Clays, \%; OM, TN, TP and TK, $\mathrm{g} \mathrm{kg}^{-1}$; AN, AP, AK, S, Cl-, B, $\mathrm{Fe}, \mathrm{Mn}, \mathrm{Cu}, \mathrm{Zn}$ and $\mathrm{Mo}, \mathrm{mg} \mathrm{kg}^{-1} ; \mathrm{Ca}^{2+}, \operatorname{coml}\left(1 / 2 \mathrm{Ca}^{2+}\right) \mathrm{kg}-1 ; \mathrm{Mg}^{2+} \operatorname{coml}\left(1 / 2 \mathrm{Mg}^{2+}\right) \mathrm{kg}^{-1}$.

Table 5. Pearson correlation coefficients between CEC and other properties.

\begin{tabular}{ccccccccccccc}
\hline $\begin{array}{c}\text { Soil } \\
\text { property }\end{array}$ & & CS & FS & Silt & Clay & pH & OM & TN & AN & TP & AP & TK \\
\hline \multirow{2}{*}{ Total 1055 } & $\mathrm{R}$ & $-.358^{* *}$ & $-.445^{* *}$ & $.277^{* *}$ & $.437^{* *}$ & $.327^{* *}$ & .041 & .049 & -.010 & $.312^{* *}$ & $.106^{* *}$ & $.253^{* *}$ \\
& $\mathrm{~S}$ & .000 & .000 & .000 & .000 & .000 & .188 & .111 & .753 & .000 & .001 & .000 \\
GY 560 & $\mathrm{R}$ & $-.330^{* *}$ & $-.375^{* *}$ & .046 & $.477^{* *}$ & .076 & -.042 & -.009 & -.051 & $.102^{*}$ & .028 & $.190^{* *}$ \\
& $\mathrm{~S}$ & .000 & .000 & .280 & .000 & .074 & .320 & .836 & .229 & .016 & .505 & .000 \\
YX 115 & $\mathrm{R}$ & $-.605^{* *}$ & $-.339^{* *}$ & $.416^{* *}$ & $.321^{* *}$ & $.371^{* *}$ & .095 & .154 & .180 & $.384^{* *}$ & $.219^{*}$ & $.224^{*}$ \\
& $\mathrm{~S}$ & .000 & .000 & .000 & .000 & .000 & .312 & .101 & .054 & .000 & .019 & .016 \\
JH 110 & $\mathrm{R}$ & -.052 & $-.350^{* *}$ & .029 & $.236^{*}$ & .151 & -.040 & -.045 & -.174 & $.198^{*}$ & .175 & $.285^{* *}$ \\
& $\mathrm{~S}$ & .592 & .000 & .764 & .013 & .116 & .677 & .638 & .069 & .038 & .068 & .003 \\
SX 45 & $\mathrm{R}$ & $-.590^{* *}$ & $-.398^{* *}$ & $.591^{* *}$ & $.513^{* *}$ & $.430^{* *}$ & .231 & .239 & .259 & $-.361^{*}$ & -.222 & .130 \\
& $\mathrm{~S}$ & .000 & .007 & .000 & .000 & .003 & .127 & .113 & .086 & .015 & .143 & .395 \\
AR 100 & $\mathrm{R}$ & $-.361^{* *}$ & $-.412^{* *}$ & $.514^{* *}$ & $.524^{* *}$ & $.603^{* *}$ & $.317^{* *}$ & $.358^{* *}$ & .175 & $.407^{* *}$ & $-.266^{* *}$ & .045 \\
& $\mathrm{~S}$ & .000 & .000 & .000 & .000 & .000 & .001 & .000 & .081 & .000 & .007 & .660 \\
YZ 96 & $\mathrm{R}$ & $-.446^{* *}$ & $-.215^{*}$ & $.367^{* *}$ & .170 & .067 & .098 & .139 & .133 & $.326^{* *}$ & $.201^{*}$ & $.398^{* *}$ \\
& $\mathrm{~S}$ & .000 & .035 & .000 & .098 & .517 & .343 & .175 & .197 & .001 & .049 & .000 \\
\hline
\end{tabular}


Table 5. Pearson correlation coefficients between CEC and other properties (Continued)

\begin{tabular}{ccccccccccccc}
\hline $\begin{array}{c}\text { Soil } \\
\text { property }\end{array}$ & & $\mathrm{AK}$ & $\mathrm{Ca}^{2+}$ & $\mathrm{Mg}^{2}$ & $\mathrm{~S}$ & $\mathrm{Cl}-$ & $\mathrm{B}$ & $\mathrm{Fe}$ & $\mathrm{Mn}$ & $\mathrm{Cu}$ & $\mathrm{Zn}$ & $\mathrm{Mo}$ \\
\hline Total 1055 & $\mathrm{R}$ & $-.123^{* *}$ & $.183^{* *}$ & $.203^{* *}$ & -.026 & $-.134^{* *}$ & $.136^{* *}$ & $-.268^{* *}$ & $.162^{* *}$ & .040 & -.051 & $.071^{*}$ \\
& $\mathrm{~S}$ & .000 & .000 & .000 & .395 & .000 & .000 & .000 & .000 & .189 & .096 & .021 \\
GY 560 & $\mathrm{R}$ & -.004 & -.027 & .041 & -.078 & $-.094^{*}$ & .017 & $-.122^{* *}$ & $.123^{* *}$ & -.043 & $-.087^{*}$ & .047 \\
& $\mathrm{~S}$ & .925 & .516 & .332 & .066 & .026 & .691 & .004 & .003 & .308 & .040 & .270 \\
YX 115 & $\mathrm{R}$ & .081 & $.260^{* *}$ & $.253^{* *}$ & -.042 & -.176 & $.321^{* *}$ & $-.213^{*}$ & -.097 & $.335^{* *}$ & -.122 & .068 \\
& $\mathrm{~S}$ & .392 & .005 & .006 & .656 & .060 & .000 & .022 & .304 & .000 & .196 & .469 \\
JH 110 & $\mathrm{R}$ & .182 & .046 & -.060 & $-.246^{* *}$ & -.139 & $.258^{* *}$ & -.141 & -.111 & .076 & -.103 & -.121 \\
& $\mathrm{~S}$ & .057 & .633 & .530 & .010 & .147 & .007 & .141 & .250 & .433 & .283 & .207 \\
SX 45 & $\mathrm{R}$ & -.072 & $.528^{* *}$ & $.640^{* *}$ & .201 & .277 & $.671^{* *}$ & $-.295^{*}$ & -.046 & -.226 & $-.351^{*}$ & -.217 \\
& $\mathrm{~S}$ & .641 & .000 & .000 & .185 & .066 & .000 & .049 & .764 & .136 & .018 & .152 \\
AR 100 & $\mathrm{R}$ & .140 & $.603^{* *}$ & $.446^{* *}$ & $.227^{*}$ & .192 & $.231^{*}$ & $-.486^{* *}$ & .093 & $.253^{*}$ & -.018 & .072 \\
& $\mathrm{~S}$ & .165 & .000 & .000 & .023 & .055 & .021 & .000 & .358 & .011 & .863 & .479 \\
& $\mathrm{R}$ & -.029 & .119 & .098 & -.097 & -.050 & $.274^{* *}$ & .074 & -.198 & $.281^{* *}$ & -.136 & -.058 \\
& & .777 & .249 & .344 & .347 & .629 & .007 & .473 & .054 & .006 & .188 & .576 \\
\hline
\end{tabular}

Note: in the first line, CS means coarse sands, FS means fine sands; In the first column, the number following the region means the number of soil samples; In the second column, R, Pearson coefficient; S, sig.(2-tailed).

Table 6. Optimal regression equation between CEC and other properties in Chenzhou

\begin{tabular}{llccc}
\hline Region & Optimal regression model & $\mathrm{R}^{2}$ & RSME & RMSE/S.D. \\
\hline Total & $\mathrm{CEC}=-0.606-0.357 \mathrm{CS}-0.133 \mathrm{FS}+0.336 \mathrm{Clay}+2.627 \mathrm{pH}+0.864 \mathrm{TP}$ & 0.407 & 5.94 & 0.77 \\
Guiyang & $\mathrm{CEC}=20.048-0.420 \mathrm{CS}-0.134 \mathrm{FS}+0.341 \mathrm{Clay}$ & 0.288 & 6.45 & 0.85 \\
Yongxing & $\mathrm{CEC}=30.655-0.593 \mathrm{CS}-0.353 \mathrm{FS}-0.342 \mathrm{Silt}+2.367 \mathrm{pH}+2.863 \mathrm{TP}-0$. & 0.489 & 6.02 & 0.74 \\
Jiahe & 608B $+0.977 \mathrm{Cu}$ & 0.123 & 5.94 & 0.94 \\
Anren & $\mathrm{CEC}=33.250-0.395 \mathrm{FS}$ & 0.602 & 3.42 & 0.66 \\
Yizhang & $\mathrm{CEC}=-1.484-0.222 \mathrm{CS}+0.110 \mathrm{Silt}+0.257 \mathrm{Clay}+0.545 \mathrm{pH}-0.023 \mathrm{OM}$ & 0.231 & 5.14 & 0.89 \\
Suxian & $+1.216 \mathrm{TN}-2.110 \mathrm{TP}+0.202 \mathrm{Ca}^{2+}+1.070 \mathrm{Mg}^{2+}+0.05 \mathrm{Fe}$ & $\mathrm{2}$ & 0.57 \\
\hline
\end{tabular}

Note: CS, coarse sands; FS, fine sands; CEC model was setup for Beihu and Linwu due to their less samples $(<20)$.

\section{Discussion}

\subsection{High CEC in tobacco-planting fields in Chenzhou}

CEC was high in tobacco-planting fields in Chenzhou, the mean value of CEC was $22.05 \mathrm{cmol}(+) \mathrm{kg}^{-1}$, higher than the very high grade of CEC $\left(\geq 20 \mathrm{cmol}(+) \mathrm{kg}^{-1}\right)$. The high $\mathrm{CEC}$ could be attributed to the high values of fine particles, $\mathrm{pH}$ and $\mathrm{OM}$ of the 
samples, because many studies have proved well that CEC usually is positively correlated with clays, $\mathrm{pH}$ and $\mathrm{OM}$, while negatively correlated with sands [5-14, 46-53], and Zhang and Zhu (1993) found that the positive contribution of silts to soil CEC could not be ignored [54]. From Table 4 it could be seen that both the contents of silts and clays were high, which were ranged from $10 \% \sim 56 \%$ and $10 \% \sim 66 \%$ with a mean of $38 \%$ and $29 \%$, respectively, in total constituted of $2 / 3$ of the particle composition. The high content of silts and clays could be attributed to that about $75 \%$ of the soil samples in Chenzhou were derived from the clayey parent materials of limestone and Quaternary red clay [42-43, 55]. $\mathrm{pH}$ value was also high in Chenzhou, ranged from 4.47 to 8.14 with a mean of $7.00,89.18 \%$ or $62.37 \%$ of the soil samples were $\geq 5.5$ or

$\geq 7.0$ in $\mathrm{pH}$. High $\mathrm{pH}$ in Chenzhou could be attributed to the samples came from the paddy-planting and to high contents of $\mathrm{Ca}^{2+}$, ranged from $2.11 \sim 83.77 \mathrm{cmol}\left(\mathrm{Ca}^{2+}\right) \mathrm{kg}^{-1}$ with a mean of $33.27 \mathrm{cmol}\left(\mathrm{Ca}^{2+}\right) \mathrm{kg}^{-1}, 85.12 \%$ of the samples were higher in $\mathrm{Ca}^{2+}(\geq 10$ cmol $\left.\left(\mathrm{Ca}^{2+}\right) \mathrm{kg}^{-1}\right)$. High $\mathrm{Ca}^{2+}$ was mostly due to superphosphate fertilizer applied for tobacco-rice, fired soil used to improve soil quality [56-57], and possibly $\mathrm{Ca}^{2+}$ was dissolved out of the limestone for most tobacco-planting fields in Chenzhou are located in the limestone hill and mountainous area [32]. Meanwhile, OM was also high in Chenzhou, ranged from $0.90 \mathrm{~g} \mathrm{~kg}^{-1}$ to $132.30 \mathrm{~g} \mathrm{~kg}-1$ with a mean of $48.00 \mathrm{~g} \mathrm{~kg}^{-1}$, and $86.06 \%$ and $90.33 \%$ of the samples were $\geq 30 \mathrm{~g} \mathrm{~kg}^{-1}$ in OM (high grade of OM). High $\mathrm{OM}$ in tobacco-planting fields in Chenzhou was decided by tobacco-rice rotation, straw returning to the field and organic fertilizer application [58-60].

\subsection{Necessity for New Transfer function of CEC}

Previous studies found that the application of the existing pedotransfer function models was usually limited in a new region due to the different backgrounds of study regions [61-62]. For example, OM is an indispensable parameter in most existing CEC models because OM is usually significantly correlated with CEC [5-14]. However, in this study no significant correlation was found between $\mathrm{OM}$ and $\mathrm{CEC}$ in most regions of Chenzhou $(\mathrm{R}=0.040 \sim 0.231$, Sig. $=0.127 \sim 6.77)$ except Anren $\left(\mathrm{R}=0.317^{* *}\right.$, Sig. $\left.=0.001\right)$, thus OM was not involved in CEC models established in this study except CEC model in Anren, which not only showed the particularity of the influencing factors of soil CEC in tobacco-planting fields in Chenzhou, but also proved again the necessity for establishing a new model for a new study region. The disappearance of OM from the CEC predicting model could also be attributed to narrower variation but high value of OM, the C.V. of OM was $61.86 \%$ of that of CEC, meanwhile, high OM more easily covers up the interchange points of cations in the process of organic-inorganic recombination [2, 63-64], both may weaken the positive contribution of OM to CEC.

\subsection{Scale Effects of CEC Predicting Model}

Most soil properties have the scale effects, and usually the larger the study area, the more influencing factors, the greater the variability of the study object, and then the lower the universality of the model established [61-62], but sometimes the real situation is not always the case [65]. In our study, it could be found that scale down (from whole Chenzhou City to six regions in Chenzhou City) caused the accuracy of CEC model increased in Yongxing, Anren and Suxian (mainly located in northeast and central of Chenzhou) while decreased in Guiyang, Jiahe and Yizhang (mainly located 
in west, southwest and south of Chenzhou), and usually the accuracy was low when less properties were significantly correlated with CEC, for examples, $\leq 3$ properties (coarse sands and clays in Guiyang, fine sands in Jiahe, coarse sands, silts and total $\mathrm{K}$ in Yizhang) were significantly correlated with CEC, so the accuracies of their CEC models $\left(\mathrm{R}^{2}=0.795^{* *}, 0.602^{* *}\right.$ and $0.489^{* *}$, and RMSE/S.D $=0.57,0.66$ and 0.74 , respectively) were lower than those of Yongxing, Anren and Suxian $\left(\mathrm{R}^{2}=0.795^{* *}\right.$, $0.602^{* *}$ and $0.489^{* *}$, and RMSE/S.D $=0.57,0.66$ and 0.74 , respectively), where $\geq 5$ properties were significantly correlated with CEC, which not only reflected the spatial complexity and differences between different regions in Chenzhou, but also proves further that it would be better to setup the optimal CEC models for different regions.

\subsection{Influences of Climate Parameters and Parent Materials on Soil CEC}

Bai et al. [66] found that climate parameters and parent materials had great influences on soil CEC, soil CEC had significant negative correlation with mean annual temperature (MAT, $\mathrm{P}<0.01)$ and quadratic function with mean annual precipitation (MAP, $\mathrm{P}<0.01$ ), and $\mathrm{CEC}$ of soils derived from glacial drifts were higher than those of soils from alluvial sediments and purple siltstone $(\mathrm{P}<0.05)$.

In this study there is only one meteorological station in each region of Chenzhou, thus, it is unreliable to use the climate data of the 8 stations to extract the information of climate parameters of each typical field through the method of spatial interpolation. However, the relationship between mean soil CEC with MAP and MAT in the eight regions was analyzed (see Table 7), and the results showed that Pearson correlation coefficients of soil CEC with MAP and MAT were -0.290 and -0.260 with Sig.(2-tailed) of 0.486 and 0.534 , respectively, which indicated no significant correlation between soil CEC and MAP and MAT, so in this study, the two climate parameters were not used in soil CEC predicating models.

Table 7. Mean values of soil CEC, annual precipitation (MAP) and air temperature (MAT).

\begin{tabular}{cccc}
\hline Region & $\begin{array}{c}\text { CEC } \\
\mathrm{cmol}(+) \mathrm{kg}^{-1}\end{array}$ & $\begin{array}{c}\text { MAP } \\
\text { Mm }\end{array}$ & $\begin{array}{c}\text { MAT } \\
{ }^{\circ} \mathrm{C}\end{array}$ \\
\hline Guiyang & 23.80 & 1385 & 17.2 \\
Yongxing & 24.11 & 1417 & 17.6 \\
Jiahe & 23.83 & 1409 & 18.3 \\
Anren & 15.31 & 1404 & 17.7 \\
Yizhang & 18.10 & 1453 & 18.7 \\
Suxian & 16.30 & 1487 & 18.2 \\
Beihu & 20.88 & 1504 & 18.4 \\
Linwu & 15.78 & 1422 & 17.9 \\
\hline
\end{tabular}

The parent material could affect soil CEC mainly through particle size distribution and clay mineral composition of the derived soil $[1,4]$. The 1055 typical fields in this study are all under tobacco and rice rotation, and all located in the flat terrains along the rivers and valleys, thus, their soil parent materials all are the alluvial materials, but the material sources of these alluvial materials might be different, which could be roughly divided into three types: limestone (limestone, dolomite, slate, etc., 883 typical fields), Quaternary red clays (41 typical fields) and sandstones (sandstone, conglomerate, granite, etc., 130 typical fields). Table 8 shows that soil CECs of 
limestone and Quaternary red clay were significantly higher than that of sandstone ( $\mathrm{P}<0.01$ and $\mathrm{P}<0.05$, respectively), which could be attributed to that clay contents were significantly higher while sand contents were significantly lower in the former two than that of the latter (see Table 9), because as shown in Table 5 that soil CEC was significantly positively correlated with clay content but negatively correlated with sand contents (coarse and fine sands).

Table 8. CECs of soils with different parent materials.

\begin{tabular}{ccccccc}
\hline Parent material & $\begin{array}{c}\text { Sample } \\
\text { no. }\end{array}$ & Minimum & Maximum & Mean \pm S.D. & Skewness & Kurtosis \\
\hline Limestone & 884 & 3.50 & 48.50 & $23.95 \pm 7.48 \mathrm{~A}$ & 0.46 & 0.03 \\
$\begin{array}{c}\text { Quaternary red } \\
\text { clay }\end{array}$ & 41 & 7.10 & 37.20 & $20.90 \pm 7.31 \mathrm{a}$ & 0.06 & -0.30 \\
Sandstones & 130 & 5.80 & 42.40 & $16.35 \pm 6.78 \mathrm{~b}$ & 1.11 & 1.98 \\
\hline
\end{tabular}

Table 9. Contents of clays $(<0.002 \mathrm{~mm})$ and sands $(2 \sim 0.02 \mathrm{~mm})$ in soils with different parent materials.

\begin{tabular}{ccccccc}
\hline \multirow{2}{*}{ Clays } & Parent material & Minimum & Maximum & Mean \pm S.D. & Skewness & Kurtosis \\
& $\begin{array}{c}\text { Limestone } \\
\text { Quaternary red } \\
\text { clay }\end{array}$ & 9.64 & 66.05 & $28.86 \pm 8.06 \mathrm{a}$ & 0.37 & 0.09 \\
& 19.48 & 46.98 & $32.21 \pm 6.88 \mathrm{~A}$ & 0.23 & -0.45 \\
\multirow{5}{*}{ Sands } & Sandstone & 13.50 & 44.29 & $26.48 \pm 6.44 \mathrm{~b}$ & 0.21 & -0.19 \\
& $\begin{array}{c}\text { Limestone } \\
\text { Quaternary red } \\
\text { clay }\end{array}$ & 12.57 & 78.56 & $32.08 \pm 8.35 \mathrm{C}$ & 12.57 & 78.56 \\
& 19.00 & 61.45 & $32.16 \pm 8.33 \mathrm{~b}$ & 19.00 & 61.45 \\
& Sandstone & 7.48 & 68.09 & $41.81 \pm 12.23 \mathrm{a}$ & 7.48 & 68.09 \\
\hline
\end{tabular}

\section{Conclusion}

This study disclosed that soil CEC averagely was high in tobacco-planting fields in Chenzhou, more than half of the tobacco fields in Chenzhou were in the very high grade of soil CEC, there were significant differences in soil CEC among different regions in Chenzhou. Different soil properties were most important for CEC predicting models in different regions, and the optimal soil CEC predicting models were different in different regions, the sampling and study region must be considered in establishing or applying the optimal soil CEC models. Soil organic matter is not a variable in soil CEC predicting models for tobacco-planting fields in Chenzhou.

\section{Acknowledgements}

This study was supported by the Project of Chenzhou Company of Hunan Tobacco Company (No. 2019-45). We would like to express thanks to those for soil sampling and analysis. 


\section{References}

[1] Huang CY. Pedology. China Agriculture Press, Beijing, 2000.

[2] Li XY. Soil Chemistry. High Education Press, Beijing, 2001.

[3] Cooperative research group on Chinese soil taxonomy. Chinese Soil Taxonomy. Science Press, Beijing and New York, 2001.

[4] Soil Survey Staff 2014a Keys to Soil Taxonomy, 12th Edition. USDA, Washington D C., 2014.

[5] Raha NS, Alhumairi BAJ. Modelling of soil cation exchange capacity for some soils of east gharaf lands from mid-Mesopotamian plain (Wasit province/Iraq). Int. J. Environ. Sci. Tech. 2019; 16: 3183-3192.

[6] Khaledian Y, Brevik EC, Pereira P, Cerdà A, Fattah MA, Tazikeh H. Modeling soil cation exchange capacity in multiple countries. Catena 2017; 158: 194-200.

[7] Shiri J, Keshavarzi A, Kisi O, Iturraran-Viveros U, Bagherzadeh A, Mousavi R, Karimi S 2017 Modeling soil cation exchange capacity using soil parameters: Assessing the heuristic models. Comput. Electron. Agr. 2017; 135: 242-251.

[8] Seyedmohammadi J, Esmaeelnejad L, Ramezanpour H. Determination of a suitable model for prediction of soil cation exchange capacity. Model. Earth Syst. Environ. 2016; 2:156. DOI 10.1007/s40808-016-0217-4

[9] Liao K, Xu S, Zhu Q. Development of ensemble pedotransfer functions for cation exchange capacity of soils of Qingdao in China. Soil Use Manag. 2015; 31: 483-490.

[10] Obalum SE, Watanabe Y, Igwe CA, Obi ME, Wakatsuki T. Improving on the prediction of cation exchange capacity for highly weathered and structurally contrasting tropical soils from their fine-earth fractions. Commun Soil Sci. Plan. Ana. 2013; 44: 1831-1848.

[11] Yukselen Y, Kaya A. Prediction of cation exchange capacity from soil index properties. Clay Miner. 2006; 41(4): 827-837.

[12] Seybold CA, Grossman RB, Reinsch TG. Predicting cation exchange capacity for soil survey using linear models. Soil Sci. Soc. Am. J. 2005; 69, 856-863.

[13] Krogh LH, Breuning M, Greve HM. Cation-exchange capacity pedotransfer functions for Danish soils. Acta Agri. Scandinavica Sec. B - Soil Plant Sci 2002; 50(1): 1-12.

[14] Manrique LA, Jones CA, Dyke PT. Predicting cation-exchange capacity from soil physical and chemical properties. Soil Sci. Soc. Am. J. 1991; 55: 787-794.

[15] Tang LN, Chen SH, Li ZB, Zeng WL, Liu XG, Jiang ZM. Main nutrients in and fertilization solutions to soil of Fujian tobacco-growing area. Tobac. Sci. Technol. 2008; (1): 56-60.

[16] Yin YQ, Luo BX, Wei ZY, Kong F. Analysis on soil fertility characteristics for tobacco planting in Hechi district of Guangxi. Guangdong Agri. Sci. 2012; (16): 84-87.

[17] Ye XF, Ling AF, Li YJ, Yang YX, Huang YJ, Chen XH, Liu GS. Evaluation of the soil fertility in tobacco-growing areas in Henan Province. Chin. J. Soil Sci., 2009; 40(6): 1303-1307.

[18] Song DT, Yao XH, Guo QZ. Analysis of soil nutrients and fertilization technology in Liangshan tobacco growing area. Acta Agri. Jiangxi, 2012; 24(12): 108-110.

[19] Li SL, Chen JB, WU WB, Kee YS, Zhan ZS, Yuan QH, Peng WS, Tan MX, Zhang ZC, Liu Y. Soil analysis to major soil in Nanxiong tobacco-growing regions. Guangdong Agri. Sci., 2011; Suppl: 103-107.

[20] Ma Y, Chen XH, Li HX. Analysis of chemical properties and nutrient status of tobacco growing soil in Qianxinan Prefecture. Till. Culti., 2009; (1): 29-30.

[21] Yuan F, Jiang DZ, Zhang YY. Study on nutrition of tobacco-growing soil in Yongzhou. Hunan Agri. Sci. 2009; (4): 55-57, 61.

[22] Song ZX, Gao M, Guan BQ, Xu AD. Soil fertility properties in the tobacco-planted area of Chongqing. Chin. J. Soil Sci. 2005; 36(5): 664-668.

[23] Qin ZL. Study on the fertility characteristics of planted tobacco soil in Guizhou. Master's Thesis, Southwest Uni., Chongqing, 2007.

[24] Li Q, Yan CB, Liu YJ, Li J, Rang ZW, Xiao YS, Li HG, Peng SG. Preliminary study on spatial distribution and influencing factors of tobacco-growing soil pH in Chenzhou. Acta Tabac. Sin. 2019; 25(3). doi: 10.16472/j.chinatobacco.2018.276.

[25] Chen YL. Study on the soil acidity characteristics and influencing factors of tobacco-planting areas in Sichuan Province. Master's Thesis, Sichuan Agri. Uni., Chengdu, 2015.

[26] Liu RT, Zhao SY, Huang YL. Potash status of major tobacco soils in Hunan Province, J. Hunan Agri. Col. 1991; 17(Suppl): 312-318.

[27] Hai HH, Zhu JF, Huang HT, Xu ZC. Relationships of soil available potassium content with soil factors and quality traits of tobacco in middle Henan Province. Acta Agri. Jiangxi 2015; 27(2): 54-57.

[28] Chang NJ, Liu QL, Li ZH, Li JY, Ma ED, Zhang YG. Grey correlation degree between ecological factors and quality of flue-cured tobacco in typical tobacco growing areas. Southwest Chin. J. Agri. Sci. 2017; 30(8): 1754-1759. 
[29] Wang H. Liangshan tobacco-growing soil nutrient impact on the quality of tobacco leaf. Master's Thesis, Henan Agri. Uni., Zhengzhou, 2012.

[30] Li YY, Qin GR, Wang L, Yu J, Xu RB, Peng WX, Rao XF. Soil nutrient elements affecting the occurrence of tobacco bacterial wilt in Qingjiang River Basin. J. Southern Agri. 2018; 49(4): 656-661.

[31] Gao FH, Chen J, Tao Q, Xu Y, Li ZH, Yang SS, Peng Y, Ju FQ. Effects of physicochemical properties of tobacco planting soil on occurrence of tobacco diseases. Hunan Agri. Sci. 2012; (9): 74-76.

[32] Editorial Committee of Tobacco Annals of Chenzhou City 2005 Tobacco Annals of Chenzhou City. Hunan People's Publishing House, Changsha, 2005.

[33] Luo DS, Wang B, Qiao XY. Explanation of national regionalization of leaves style of flue-cured tobacco. Acta Tabac. Sin. 2019; 25(4): 1-9.

[34] Gao X, Zhou LK, Guo T, Li HG, Deng XH, Xiao YS, Li Q. Spatial and temporal variability of soil organic matter and total nitrogen and influencing factors in Chenzhou tobacco-growing area, Hunan Province. Chin. J. Soil Sci. 2020; 51(3): 686-693.

[35] Guo T, Li HG, Li W, Peng SG, Xiao CS, Li J, Liu YJ, Xiao YS, Li LJ, Li Q. Spatial-temporal variability and factors to influence boron availability in tobacco-planting soils of rotating paddy-upland fields in southern Hunan. Tobac. Sci. Technol. 2019; 52(7): 27-34.

[36] Li Q, Yan CB, Liu YJ, Li J, Rang ZW, Xiao YS, Li HG, Peng SG. Preliminary study on spatial distribution and influencing factors of tobacco-growing soil $\mathrm{pH}$ in Chenzhou. Acta Tabac. Sin. 2019; 25(3). doi: 10.16472/j.chinatobacco.2018.276.

[37] Kuang CF, Zhou GS, Deng ZP, Li XY, Cheng JP, Shi XB, Xiao HQ; Li MD. Soil nutrient status in Chenzhou tobacco planting areas. Acta Tabac. Sin. 2020; 31(3): 33-37.

[38] Zhang GL, Gong ZT. Soil Survey Laboratory Methods. Science Press, Beijing, 2012.

[39] Bao SD. Soil Agrochemical Analysis (the 3rd edition). China Agriculture Press, Beijing, 2000.

[40] Lu RK. Methods for agricultural chemical analysis of soils. China Agricultural Science and Technology Press, Beijing, 2000.

[41] Agricultural Chemistry Specialized Committee of Chinese Society of Soil Science 1983 Methods for Conventional Analysis of Soil Agrochemistry. Science Press, Beijing. 1983.

[42] Li QK, Xiong Y. Soils of China. 2nd Edition, Science Press, Beijing, 1990.

[43] Soil survey office of China. Soils of China. China Agriculture Press, Beijing, 1998.

[44] $\mathrm{Yu} \mathrm{JH}, \mathrm{He} \mathrm{XH}$. Data statistical analysis and SPSS applications. Posts \& Telecommunications Press, Beijing, 2003.

[45] Nielsen DR, Bouma J. Soil spatial variability. Proceedings of a workshop of the ISSS and SSSA, Las Vegas, USA/Pdc296. Pudoc Netherlands: Wageningen, 1985.

[46] Bai ZQ, Zhang SR, Zhong QM, Wang GY, Xu GR, Ma XJ. Characteristics and impact factors of soil cation exchange capacity (CEC) in western margin of Sichuan Basin. Soils 2020, 52(3): 581-687.

[47] Liao K, Xu S, Zhu Q. Development of ensemble pedotransfer functions for cation exchange capacity of soils of Qingdao in China. Soil Use Manage. 2015; 31: 483-490.

[48] Wang WY, Zhang LP, Liu Q. Distribution and affecting factors of soil cation exchange capacity in watershed of the Loess plateau. J. Soil Water Conserv. 2012; 26(5): 123-127.

[49] Cheng XF, Zhu H, Hao LX, Shi XZ. Spatial predication of soil cation exchange capacity (CEC) in hilly region. Chin. J. Appl. Environ. Biol. 2008; 14(4): 484-487.

[50] Liu SQ, Pu YL, Zhang SR, Wang CQ, Deng LJ. Spatial change and affecting factors of soil cation exchange capacity in Tibet. J. Soil Water Conserv. 2004; 18(5): 1-5.

[51] Zhao ZZ. Study on relationship between organic matter, soil fractions and CEC in Qinghai soil. Sci. Technol. Qinghai Agri. Fores. 2004; (4): 4-6.

[52] Xu MG, Zhang JX, Zhang H, An ZS. Study on the influencing factors of cation exchange capacity of Heilutu and yellow-brown soil. Chin. J. Soil. Sci. 1991; 22(3): 108-110.

[53] Xu MG, An ZS. A study on the relationship between the mineral compositions and the cation exchange capacity in Shaanxi soils. Acta Uni. Sep. Occident. Agri. 1988; 2(6): 310 -313.

[54] Zhang MK, Zhu Z X. Effect of silts on cation exchange capacity in soil. Soil Fertil. 1993; (4): 41-43.

[55] Xu JP, Li JG, Wei YJ, Zhang GH, Yang BG, Cai CF. Fractal characteristics of particle composition for soils developed from different parent materials. Acta Pedo. Sin. 2020; 57(5): 1197-1205.

[56] Li XC, Li HG, Xiao YS, Song WJ, Zheng XB, Dong JX. Effects of fired soil on root growth and rhizosphere nutrients of tobacco at seedling stage. Chin. Tobac. Sci. 2020; 41(5): 43-48.

[57] Kuang CF, Li HG, Xu QX, Li XY, Huang CY, Fang M, Luo JR, Li YX. Study on improving rhizosphere environment of flue-cured tobacco by applying ash soil. Agri. Devel. Equip. 2013; (9): $52-53$.

[58] Gao X, Zhou LK, Guo T, Li HG, Deng XH, Xiao YS, Li Q. Spatial and temporal variability of soil organic matter and total nitrogen and influencing factors in Chenzhou tobacco-growing area, Hunan Province. Chin. J. Soil Sci. 2020; 51(3): 686-693. 
[59] Wang XD, Zhuang JJ, Liu BY, Li SS, Zhao X, Liu Y, Zhang HL. Residue returning induced changes in soil organic carbon and the influential factors in China's croplands: A meta-analysis. J. Chin. Agri. Uni. 2020; 25(8)L 12-24.

[60] Jin ZL, Jia SC, Peng SG, Liu YJ. Effects of the application level of cake fertilizer on the growth and quality of flue cured tobacco in high organic matter-field of south Hunan. Crop Res. 2018; 32(6): 516-520.

[61] Van LK, Bouma J, Herbst M, Koestel J, Minasny B, Mishra U, Montzka C, Nemes A, Pachepsky YA, Padarian J, Schaap MG, Tóth B, Verhoef A, Vanderborght J, Van der Ploeg MJ, Weihermüller L, Zacharias S, Zhang YG, Vereecken H. Pedotransfer functions in Earth system science: Challenges and perspectives. Rev. Geophys. 2017; 55: 1199-1256.

[62] McBratney AB, Minasny B, Cattle SR, Vervoort RW. From pedotransfer functions to soil inference systems. Geoderma 2002; 109: 41- 73

[63] Desilva JA, Toth ST. Cation-exchange reactions, electrokinetic and viscometric behavior of clay-organic complexes. Soil Sci. 1964; 97(1): 63-73.

[64] Ji GL. Soil electrochemical properties and their research methods (revised edition). Science Press, Beijing, 1980.

[65] Ge C, Liu HL, Nie CJ, Shen Q, Zhang SW. Scale effect of soil fertility spatial variability and its influencing factors. Resour. Sci. 2019; 41(4): 753-765.

[66] Bai ZQ, Zhang SR, Zhong QM, Wang GY, Xu GR, Ma XJ. Characteristics and impact factors of soil cation exchange capacity (CEC) in western margin of Sichuan basin. Soils 2020; 52(3): 581-587. 